\title{
Growth of bacterial phytopathogens in animal manures
}

\author{
Wojciech Sledz ${ }^{1}$, Sabina Zoledowska' ${ }^{1}$, Agata Motyka', Leszek Kadziński ${ }^{2}$ and \\ Bogdan Banecki
}

1Department of Biotechnology, Intercollegiate Faculty of Biotechnology, University of Gdansk and Medical University of Gdansk, Gdansk, Poland; 2Department of Molecular and Cellular Biology Intercollegiate Faculty of Biotechnology, University of Gdansk and Medical University of Gdansk, Gdansk, Poland

\begin{abstract}
Animal manures are routinely applied to agricultural lands to improve crop yield, but the possibility to spread bacterial phytopathogens through field fertilization has not been considered yet. We monitored 49 cattle, horse, swine, sheep or chicken manure samples collected in 14 Polish voivodeships for the most important plant pathogenic bacteria - Ralstonia solanacearum (Rsol), Xanthomonas campestris pv. campestris (Xcc), Pectobacterium carotovorum subsp. carotovorum (Pcc), Pectobacterium atrosepticum (Pba), Erwinia amylovora (Eam), Clavibacter michiganensis subsp. sepedonicus (Cms) and Dickeya sp. (Dsp). All of the tested animal fertilizers were free of these pathogens. Subsequently, the growth dynamics of $\mathrm{Pba}$, Pcc, Rsol, and Xcc in cattle, horse, swine, sheep and chicken manures sterilized either by autoclaving or filtration was evaluated. The investigated phytopathogens did not exhibit any growth in the poultry manure. However, the manure filtrates originating from other animals were suitable for microbial growth, which resulted in the optical density change of $0.03-0.22$ reached within $26 \mathrm{~h}$ (48 h Rsol, $120 \mathrm{~h} \mathrm{Xcc}$ ), depending on bacterial species and the manure source. Pcc and Pba multiplied most efficiently in the cattle manure filtrate. These bacteria grew faster than Rsol and Xcc in all the tested manure samples, both the filtrates and the autoclaved semi-solid ones. Though the growth dynamics of investigated strains in different animal fertilizers was unequal, all of the tested bacterial plant pathogens were proven to use cattle, horse, swine and sheep manures as the sources of nutrients. These findings may contribute to further research on the alternative routes of spread of bacterial phytopathogens, especially because of the fact that the control of pectionolytic bacteria is only based on preventive methods.
\end{abstract}

Key words: animal manure, plant protection, Ralstonia solanacearum, Xanthomonas campestris, Erwinia amylovora, Dickeya solani, Pectobacterium carotovorum subsp. carotovorum, Pectobacterium atrosepticum

Received: 08 July, 2016; revised: 27 July, 2016; accepted: 06 September, 2016; available on-line: 17 March, 2017

e-mail:wojciech.sledz@biotech.ug.edu.pl

Abbreviations: Ralstonia solanacearum (Rsol), Xanthomonas campestris pv. campestris (Xcc), Dickeya solani (Dsol), Pectobacterium carotovorum subsp. carotovorum (Pcc), Pectobacterium atrosepticum (Pba), Dickeya sp. (Dsp), Erwinia amylovora (Eam)

\section{INTRODUCTION}

Manures that are routinely applied to agricultural lands maintain or improve crop yield by increasing the amount of organic matter in the soil, attaining its biological ac- tivity, but also boosting its chemical and physical properties (Haynes \& Naidu, 1998). According to agricultural census data (HMSO, 1993), the annual production of livestock excreta equals roughly 190 million tonnes in the UK, of which approx. 80 million tonnes are collected within the farm buildings or yards. After proper handling and storage, natural fertilizers of value estimated at £200 mln per year on the basis of N, P and K contents are applied on the farmlands (Smith et al., 1998). As reported by The British Survey of Fertilizer Practice, $18 \%$ of the tillage areas and $48 \%$ of the grasslands are subjected to organic fertilizer treatment (Burnhill et al., 1994). Utilizing animal manures collected from feedlots and housed livestock has received renewed attention due to the growing interest in the disposal of wastes, also including sewage sludge or composed municipal wastes (Haynes \& Naidu, 1998). As stated by the United States Department of Agriculture Natural Resources Conservation Service, chicken broilers and dairy lactating cows produce over $80 \mathrm{lbs}$ per day per 1000-lb animal unit of total manure, being more efficient in comparison to hogs and pigs, layer chicken, beef on high forage diet and turkeys that provide 63.1, 60.5, 59.1 and 43.6, respectively (USDA-NRCS, 1992). Total amount of $\mathrm{N}$ and $\mathrm{P}$ originating from manures dispersed at agricultural rates depends strongly on the animal source as well. Manure collected from chicken broilers is the richest source of both, $\mathrm{N}$ and $\mathrm{P}$, yielding 1.10 and $0.34 \mathrm{lbs}$ per day per $1000-\mathrm{lb}$ animal unit of these elements. In contrast, excreta obtained from beef and dairy cows exhibit the lowest amounts of these elements: 0.31 and 0.45 of $\mathrm{N}, 0.11$ and 0.07 of P (USDA-NRCS, 1992). In addition, Sauerbeck (1982) demonstrated that the amount of $\mathrm{C}$ accumulated in soil vary considerably depending on the decomposition rate of the organic matter applied. It is worth mentioning that the water content of the manure and the labour needed for its collection are important factors affecting the preference of the farmyard manure used. Horse manure is considered to be the easiest to handle due to its low water saturation level, however, the process of gathering wetter material derived from pigs or cows does not require hand-collecting from the fields.

The major environmental concerns connected with applying farmyard manures focus on water and soil pollution resulting from direct discharge or runoffs. Most widely discussed issues involve leaching of $\mathrm{N}$ and $\mathrm{P}$ leading to aquatic eutrophication, residues of veterinary antibiotics and sheep-dips, odors exceeding tolerable levels, or bacterial, viral and protozoan contamination of the natural ecosystems (Hooda et al., 2000; Zhao et al., 2010; Jongbloed \& Lenis, 1998). 
It was proven that the pig, cattle and poultry manures from intensive farming harbour pathogenic bacteria such as Escherichia coli, Listeria monocytogenes, Campylobacter spp. and Salmonella spp. (Kearney et al., 1993). For example, strains of Salmonella sp. were isolated from pig slurry and it was shown that they retain viability in the manure for more than 30 months (Jones \& Hall, 1975; Morse \& Duncan, 1974). Subsequent studies by Jones (1980) indicated that although $90 \%$ of Salmonella sp. cells die during the first two to four weeks of storage, still approx. 100 cells per gram of slurry remain alive (Jones, 1980). In addition, Salmonella spp. were proven to sustain 4-30 weeks in chicken litter (Tucker, 1967), 16-26 weeks on wheat (Crumrine \& Foltz, 1967), and up to 16 months in animal feed (Williams \& Benson, 1978). Lowering bacterial viability could be achieved by implementing mesophilic anaerobic digestion that was proven to be effective not only in reducing the organic content of slurry, but also in decreasing for instance the viable counts of Salmonella typhimurium by one logarithmic unit in 2 days within the pig-feed digesters (Olsen \& Larsen, 1987). The source and type of slurry, $\mathrm{pH}$, temperature, concentration of volatile fatty acids, origin and species of the investigated microorganism have substantial effect on the survival of bacterial pathogens in anaerobic digesters (Tappouni, 1984).

Besides considerable amount of data concerning the threat of spreading human and animal pathogens by applying pig, cattle or poultry manures on the arable lands, little is known about the impact of natural fertilizer treatment on dissemination of plant pathogenic bacteria. Many microorganisms that cause disease symptoms on plants under permissive conditions can also exist as epiphytes or saprophytes in plant tissues that are ingested by farmyard animals (Leben, 1974). According to the best of our knowledge, there is no data on the survival of phytopathogenic bacteria within livestock intestines or on animal feed. In general, plant pathogenic bacteria are not thought to survive the composting or sewage treatment (Mikkelsen et al., 2006). It was proven that they can persist in soil only for a limited period of time, while the moisture, temperature, $\mathrm{pH}$, UV light and natural microbiota strongly affect their survival rate (Killham, 1994).

Phytopathogens belonging to the species: Ralstonia solanacearum (Rsol), Xanthomonas campestris, Pectobacterium carotovorum and Pectobacterium atrosepticum (Pba) are listed within the top 10 plant pathogenic bacteria causing the most severe losses in plant cultivation (Mansfield et al., 2012).

Rsol is a quarantine organism due to its lethality, persistence, wide host range and broad geographic distribution and needs to be eradicated by all means (Elphinstone, 2005). The outcome of infection by this Gram(-) soil-borne bacterium includes yellowing, wilting, generalized necrosis and death of the host due to bacterial invasion of plant roots, cortical tissue and the vascular system. Control strategies against bacterial wilt employ integrated disease management strategies like planting pathogen-free material originating preferably from less susceptible host varieties or implementing the crop rotation system (Denny, 2007).

Gram(-) Xanthomonas campestris pv. campestris (Xcc) is responsible for black rot in the crucifer family Brassicaceae. Characteristic symptoms of Xcc infections involve blackening of the plant tissues, chlorotic to necrotic lesions at the foliar margin in addition to subsequent wilting, stunting and rotting. Numerous epidemics have been reported worldwide, particularly aggravated in the developing regions of Africa and Asia due to the higher humidity and average temperatures (Qian et al., 2005).

Pectinolytic pathogens formerly belonging to Erwinia spp. are now classified to the Dickeya and Pectobacterium genera. These Gram(-) rod-shaped necrotrophs degrade plant tissue via secretion of exoenzymes such as pectinases, proteases and cellulases (Hugouvieux-Cotte-Pattat et al., 1996). Pba is believed to cause blackleg and soft rot only on potato, while $P$. carotovorum subsp. carotovorum (Pcc) and Dickeya spp. (Dsp) are responsible for severe soft rotting symptoms of many crops and ornamentals (Perombelon, 2002). Importantly, no chemical or biological methods to eradicate these pathogens are commercially available, and the disease control is based only on the preventive measures (Czajkowski et al., 2011). Severe economic losses caused by Pectobacterium and Dickeya spp. result from decreased crop yield reaching e. g. 20-25\% in Israel (Tsror et al., 2009) or rejection of infected seed tuber lots, which adds up to $30 \mathrm{M} €$ annually in the Netherlands (Toth et al., 2011).

The first goal of this study was to monitor animal manures originating from small farms where the livestock was fed with the household own cultivation for the presence of bacterial phytopathogens. The next step was to evaluate in vitro the growth of plant pathogenic bacteria - Pba, Pcc, Rsol, and Xcc - in filtrates and semi-solid fractions of poultry, cattle, horse, swine, and sheep manures. To the best of our knowledge, research presented here is the first one trying to answer the question whether plant pathogenic bacteria can utilize fertilizers of animal origin as the sources of nutrients. The obtained data might contribute to revealing a possible way of phytopathogens' spreading in the fields.

\section{MATERIALS AND METHODS}

Bacterial strains, growth media and culture conditions. Strains of bacteria used in this study are listed in Table 1.

Table 1. Growth conditions applied for the investigated bacterial phytopathogens.

\begin{tabular}{|c|c|c|c|c|}
\hline Bacterial species & Strain & Growth temperature $\left[{ }^{\circ} \mathrm{C}\right]$ & Solid medium & Liquid medium \\
\hline Pectobacterium atrosepticum (Pba) & SCRI 1043 & 28 & LA & LB \\
\hline Pectobacterium carotovorum subsp. carotovorum (Pcc) & SCRI 180 & 28 & LA & LB \\
\hline Ralstonia solanacearum (Rsol) & LMG 2294 & 28 & $\begin{array}{l}\text { TZC } \\
+A\end{array}$ & TZC \\
\hline Xanthomonas campestris pv. campestris (Xcc) & LMG 582 & 28 & $\mathrm{GF}+\mathrm{A}$ & GF \\
\hline
\end{tabular}

LMG, BCCM/LMG Bacteria Collection, Gent, Belgium; SCRI, Scottish Crop Institute, Dundee, Scotland; LB, Lysogeny Broth medium (Bertani, 1951); LA, LB + A; GF, Growth Factor medium (Agarwal et al., 1989); TZC medium, 2,3,5-triphenyl tetrazolium chloride (French et al., 1995); A, agar 15 g I-1 
The following growth media were used for conducting bacterial cultures: LB (Bertani, 1951), GF (Agarwal et al., 1989), and TZC (French et al., 1995). Agar - $15 \mathrm{~g}$ $\mathrm{1}^{-1}$ - was added to prepare the corresponding solid media. The media and growth conditions applied for the investigated plant pathogenic bacteria are presented in Table 1.

Animal manure samples used in this study. To perform this research, 20 cattle, 12 horse, 6 swine, 10 sheep and 1 chicken raw manure samples were collected from 49 different agricultural holdings on the territory of 14 Polish voivodeships. Farmers involved in this research provided their livestock only with feed derived from their own crop production. Geographical location of the collected fertilizers and the animal origin of the manures are depicted in Fig. 1. More detailed data on the investigated natural fertilizers are listed in the Supplementary Table 1.

Monitoring of the manure samples for the presence of phytopathogens. Total genomic DNA was isolated from 49 manure samples using Genomic Mini AX Stool Kit (A\&A Biotechnology, Gdynia, Poland) according to the manufacturer's guidelines. Then, $2 \mathrm{x}$ diluted DNA was used for specific single PCR-based detection of bacterial phytopathogens of interest. The following primer pairs targeting listed microorganisms were used: Y45/Y46 for Pba (Frechon et al., 1998), ExpccF/ExpccR for Pcc (Kang et al., 2003), ADE1/ADE2 for Dsp (Nassar et al., 1996), Oli-1/Y2 for Rsol (Seal et al., 1993), A/B for Eam (Bereswill et al., 1992), PSA-1/PSA-R for Clavibacter michiganensis subsp. sepedonicus (Cms) (Pastrik, 2000), and XCR/XCF for Xcc (Park et al., 2004). Electrophoretic separation of the obtained amplicons was performed in $1.5 \%$ agarose gel soaked in $0.5 \mathrm{x}$ TBE buffer and the run lasted for $45 \mathrm{~min}$ at $100 \mathrm{~V}$. Gels were stained with ethidium bromide and subsequently visualized utilizing Bio-Rad Gel Doc system (Hercules, California, USA).

Manure samples artificially inoculated with $10^{5}$ CFUs of Pba, Pcc, Dsp, Rsol, Eam, Cms or Xcc were prepared for testing the efficacy of total DNA isolation and sub-

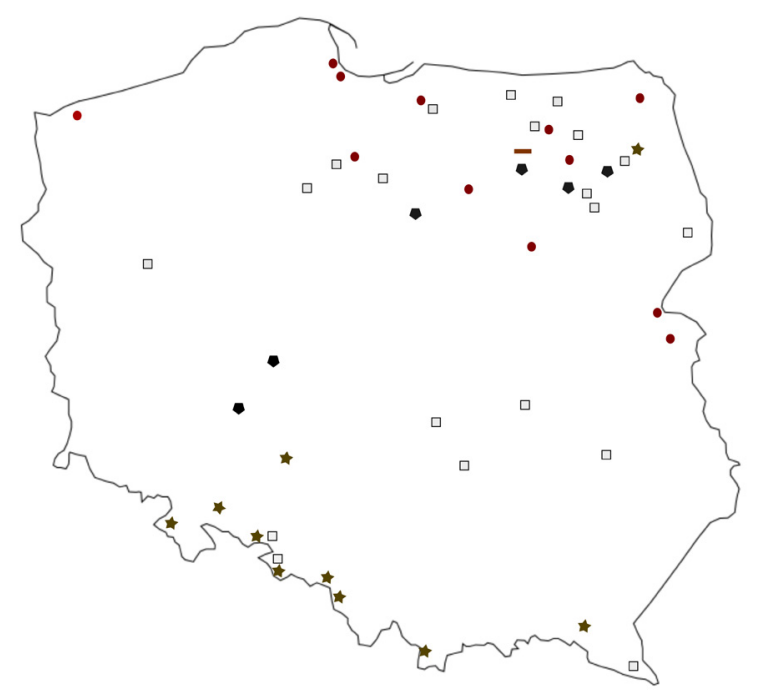

Figure 1. Geographical location and animal origin of the collected manure samples.

This figure depicts the map of Poland with the following symbols representing the sampling points for collection of certain animal manures: squares, cattle manure; circles, horse manure; stars, sheep manure; pentagon, swine manure; rectangle, chicken manure. sequent PCR reactions. All positive controls provided specific DNA amplicons under the applied conditions.

Evaluation of bacterial growth dynamics in filtrates from animal manures. Cattle, horse, swine, sheep and chicken manures mixed from samples collected in different locations were diluted 1:3 in Ringers buffer (Sigma-Aldrich, St. Louis, USA) and incubated for $30 \mathrm{~min}$ with shaking $(150 \mathrm{rpm})$ at room temperature. Then, the suspensions were sterilized by filtration using the following filters in a sequence: 5, 1.2, 0.8, 0.45, $0.22 \mu \mathrm{m}$ Minisart SRP Syringe Filters (Sartorius, Goettingen, Germany). Obtained sterile manure suspensions were transferred to 24-well microplates (Sarstedt, Nuembrecht, Germany) and inoculated with $10^{2}-10^{3} \mathrm{CFUs}$ of the following phytopathogens: Pba, Pcc, Rsol and Xcc. Bacterial growth curves were plotted on the basis of $\mathrm{OD}_{580}$ measurements performed utilizing Victor $3 \mathrm{~V}$ Multilabel Plate Reader (Perkin Elmer, US) after 0, 18, 26 h of incubation (for Rsol and Xcc, the cultures were conducted up to 48 and $120 \mathrm{~h}$, respectively, due to lower growth rate of these species). In order to provide controls, optimal media (Table 1) were inoculated with the investigated bacterial plant pathogens. Also, the change in absorbance at $580 \mathrm{~nm}$ of non-inoculated manure filtrates was measured. The whole procedure was repeated at least three times.

Evaluation of bacterial growth in sterilized semisolid animal manures. Cattle, horse, swine, sheep and chicken manures mixed from samples collected in different locations were diluted $1: 3$ in a Ringers buffer (Sigma-Aldrich) and incubated for $30 \mathrm{~min}$ with shaking $(150 \mathrm{rpm})$ at room temperature. Then, the suspensions were autoclaved for $40 \mathrm{~min}$ at $121^{\circ} \mathrm{C}, 0.7 \mathrm{~atm}$. Because of 2-3 unit decrease in the $\mathrm{pH}$ values of the autoclaved manure samples, $\mathrm{NaOH}$ was used to adjust the $\mathrm{pH}$ to the initial one (in the range of 6.8-7.9, depending on the sample). $100 \mathrm{ml}$ of sterilized manure samples were inoculated with $1 \mathrm{ml}$ containing $10^{2}-10^{3}$ CFUs of the following phytopathogens: Pba, Pcc, Rsol and Xcc. Bacterial cultures in investigated animal manures were incubated with shaking $(150 \mathrm{rpm})$ at the optimal temperatures (Table 1). After incubation time lasting 0, 10, 18, 26, and $120 \mathrm{~h}, 100 \mu \mathrm{l}$ of each culture was spread on plates containing optimal growth media (Table 1). Colony forming units were counted or in the case of bacterial lawn, the growth was assessed visually in comparison to the controls.

Statistical analysis. The absorbance of cultures of the investigated bacterial phytopathogens in the animal manure filtrates was compared to the absorbance of the incubated manure samples alone by preferably utilizing unpaired $t$-tests at $p<0.05$. Shapiro-Wilk normality test was used to check whether collected sets of data follow the Gaussian distribution. Equality of variances between two populations was examined by the Levene's test. If certain dataset did not meet the $t$-test requirements, the Wilcoxon-Mann-Whitney test was used. Statistica 7 (StatSoft Inc., USA) software was used for performing all of the calculations.

\section{RESULTS}

\section{Monitoring of manure samples for the presence of phytopathogens}

49 Samples of animal manures were investigated for the presence of DNA of the following plant pathogenic 
154

W. Sledz and others

2017
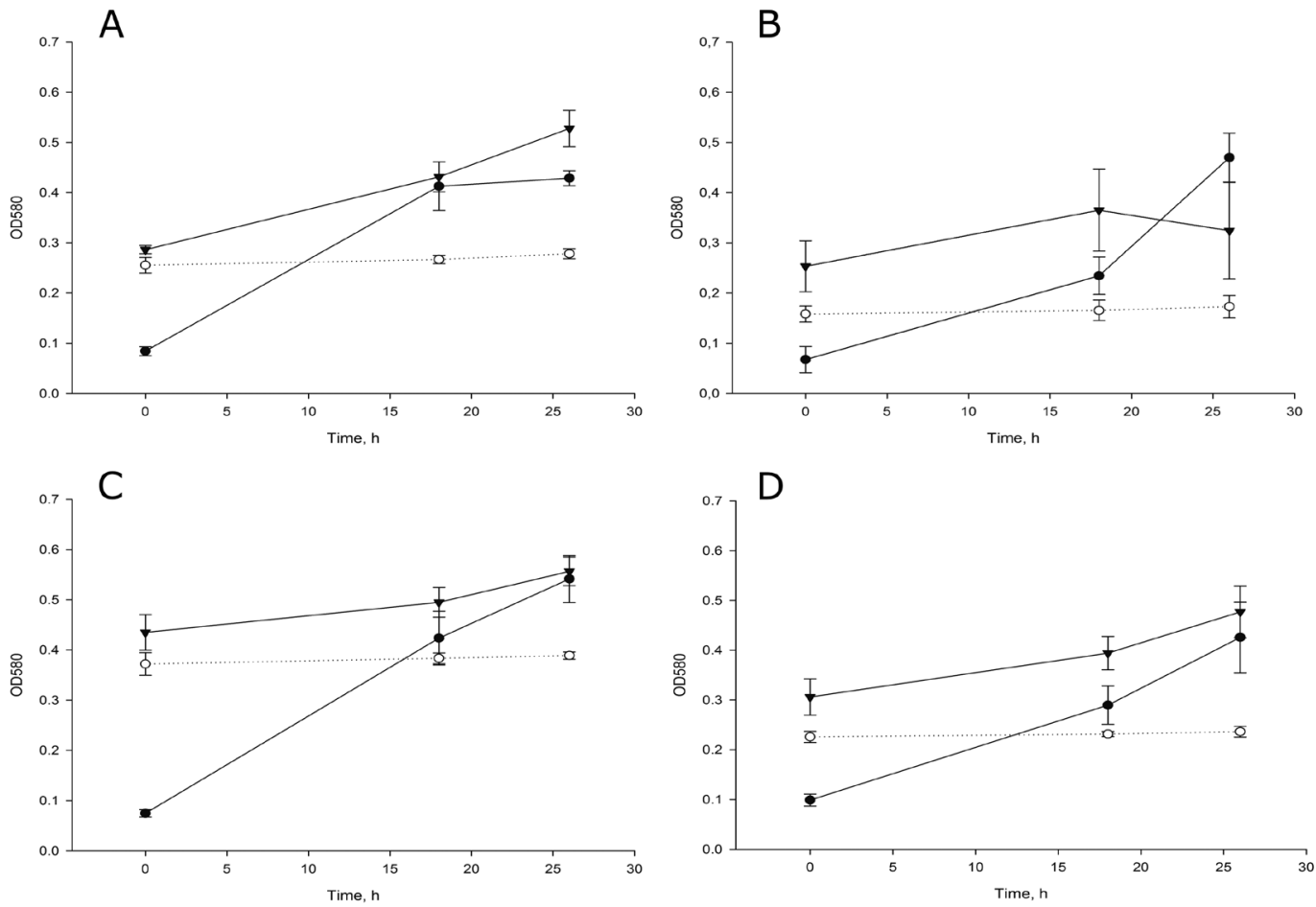

Figure 2. Growth dynamics of $P$. atrosepticum SCRI 1043 in the animal manures:

(A) cattle, (B) horse, (C) sheep, (D) swine. Values are means \pm S.D. Plot with black triangles is representing the growth of $P$. atrosepticum in animal manure. Plot with black dots is showing the control growth of $P$. atrosepticum in LB medium. Dotted line with white circles is representing the absorbance of animal manure at $580 \mathrm{~nm}$.
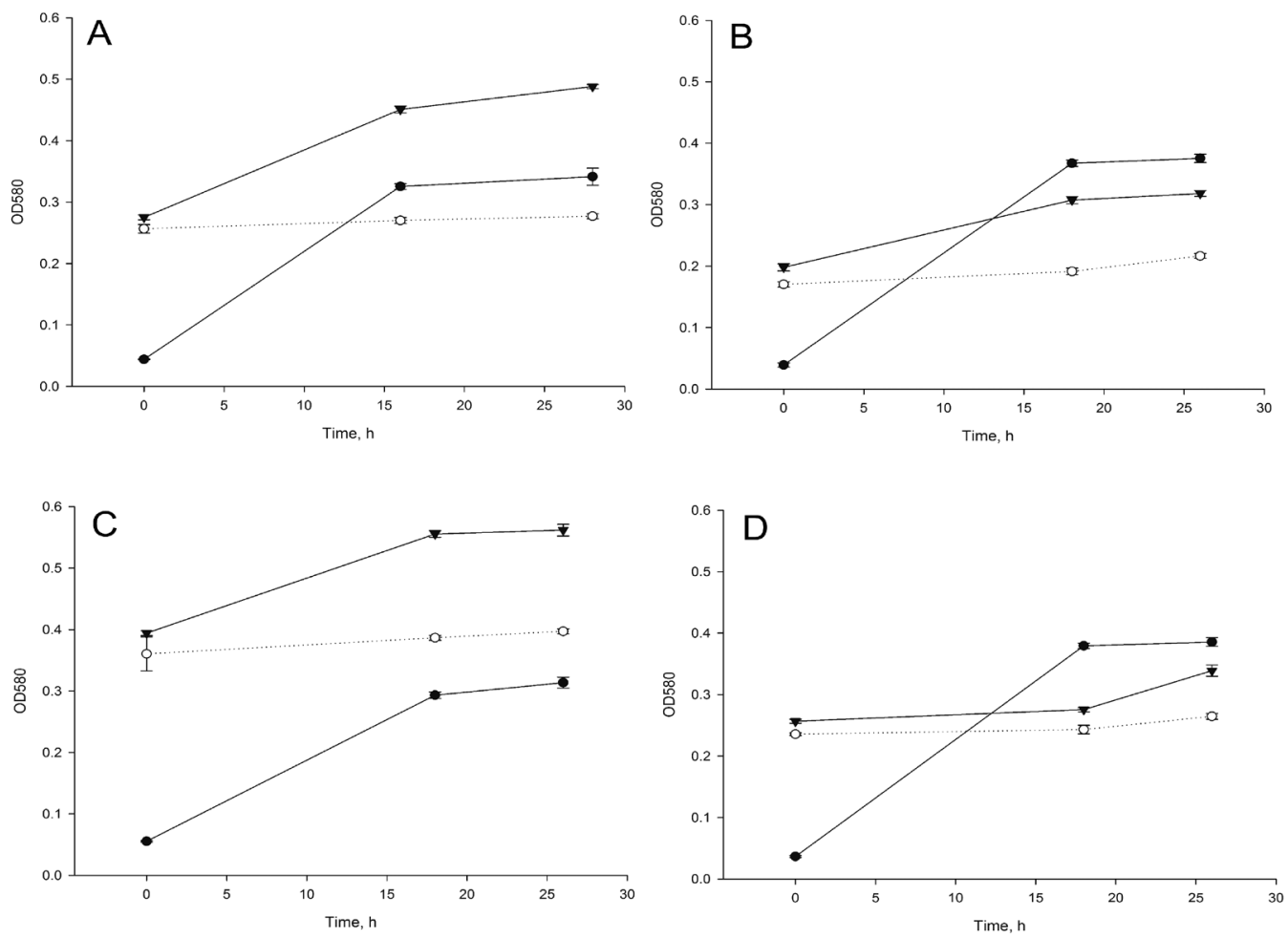

Figure 3. Growth dynamics of $P$. carotovorum subs. carotovorum SCRI 180 in the animal manures:

(A) cattle, (B) horse, (C) sheep, (D) swine. Values are means \pm S.D. Plot with black triangles is representing the growth of $P$. carotovorum subsp. carotovorum in animal manure. Plot with black dots is showing the control growth of $P$. carotovorum subsp. carotovorum in LB medium. Dotted line with white circles is representing the absorbance of animal manure at $580 \mathrm{~nm}$. 
Table 2. Relative differences in the optical densities of plant pathogenic bacteria cultures conducted in the filtrates of cattle, horse, swine and sheep manures

Relative difference in $\mathrm{OD}_{580}$ of cultures conducted in filtrates of animal manures

\begin{tabular}{|c|c|c|c|c|}
\hline Phytopathogen & Cattle & Horse & Swine & Sheep \\
\hline Pba & 0.218592 & 0.05621 & 0.160495 & 0.104555 \\
\hline Pcc & 0.192525 & 0.073921 & 0.053174 & 0.130683 \\
\hline Xcc & 0.025503 & 0.113095 & 0.105614 & 0.105755 \\
\hline Rsol & 0.088916 & 0.104117 & 0.086813 & 0.081596 \\
\hline
\end{tabular}

The $\mathrm{OD}_{580}$ values at the incubation start and end points ( $26 \mathrm{~h}$ for Pcc and $\mathrm{Pba}, 48 \mathrm{~h}$ for Rsol, and $120 \mathrm{~h}$ for $\mathrm{Xcc}$ ) were used to calculate the above presented relative differences. The change in $\mathrm{OD}_{580}$ of the non-inoculated filtrates was subtracted as the background noise.

bacteria: Cms, Dsol, Eam, Pba, Pcc, Rsol and Xcc. All of the tested manure samples, with no dependence on the geographical or animal origin of the fertilizer, were free of the above-listed pathogens (Supplementary Table 1 at www.actabp.pl).

\section{Bacterial growth dynamics in filtrates from animal manures}

The growth efficiency of bacterial phytopathogens in animal manure filtrates was examined. All tested plant pathogenic bacteria (Pcc, Pba, Rsol and Xcc) did not exhibit any growth in the filtrate of the poultry manure. However, as depicted in Table 2, each of the investigated microorganisms did show difference in growth by a change in $\mathrm{OD}_{580}$, comprising in the range of $0.03-$ 0.22 when cultured in the filtrates from cattle, horse, swine, and sheep manures for $26 \mathrm{~h}(48 \mathrm{~h}$ for Rsol,
$120 \mathrm{~h}$ for Xcc). We observed some variability between species in the effectiveness of utilizing nutrients available in the filtrates of the studied manures. The growth of $\mathrm{Pba}$ and Pcc was the greatest in the filtrate of cattle manure. Rsol exhibited similar growth rate in the tested manure filtrates with slight preference for the horse one. In the terms of Xcc, this pathogen was using filtrate from horse manure the most efficiently, although the other manures, with the exception of the cattle one, supported its growth in a comparable manner.

Concerning growth dynamics in the analyzed filtrates of animal manures, Pba and Pcc started multiplying quite instantly after inoculation, with a notable exception of delayed and less efficient growth of Pcc in the filtrate of swine manure (Fig. 2 and Fig. 3). In the case of Rsol, we have observed a significant increase in the culture densities no sooner than
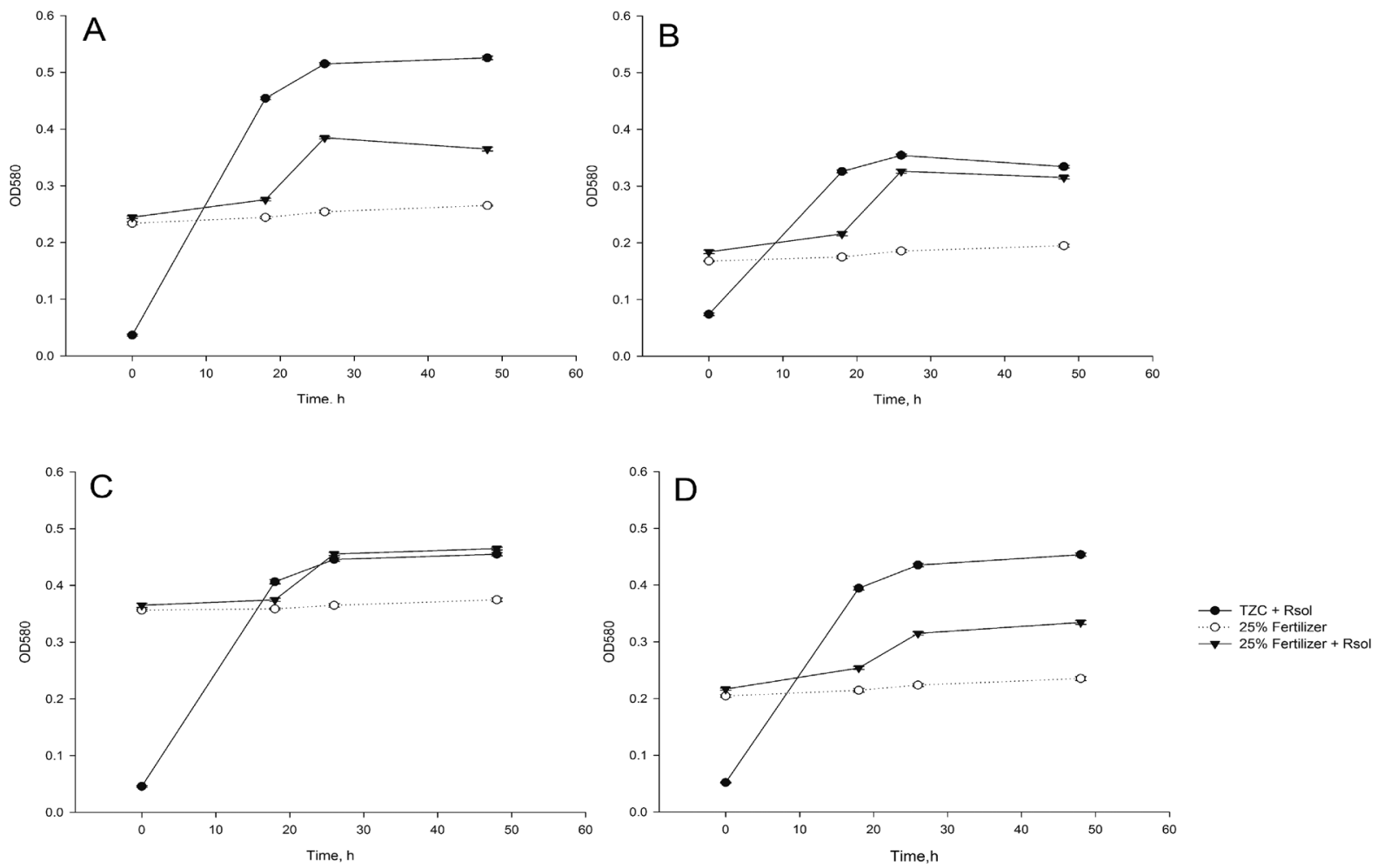

Figure 4. Growth dynamics of $R$. solanacearum LMG 2294 in the animal manures:

(A) cattle, (B) horse, (C) sheep, (D) swine. Values are means \pm S.D. Plot with black triangles is representing the growth of $R$. solanacearum in animal manure. Plot with black dots is showing the control growth of $R$. solanacearum in TZC medium. Dotted line with white circles is representing the absorbance of animal manure at $580 \mathrm{~nm}$. 

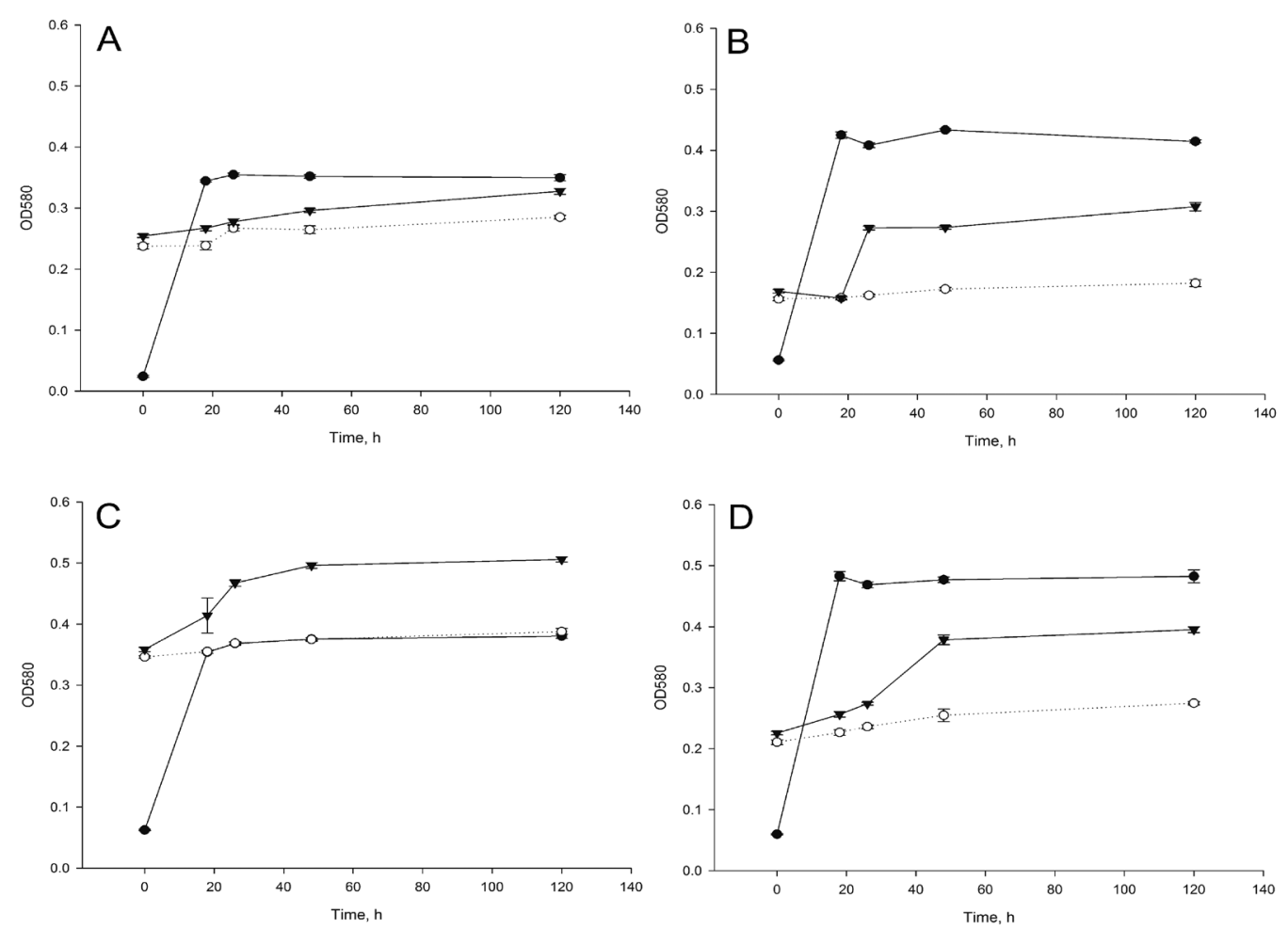

Figure 5. Growth dynamics of Xanthomonas campestris pv. campestris LMG 582 in the animal manures:

(A) cattle, (B) horse, (C) sheep, (D) swine. Values are means \pm S.D. Plot with black triangles is representing the growth of Xanthomonas campestris pv. campestris in animal manure. Plot with black dots is showing the control growth of Xanthomonas campestris pv. campestris in GF medium. Dotted line with white circles is representing the absorbance of animal manure at $580 \mathrm{~nm}$.

after $16 \mathrm{~h}$ of incubation (Fig. 4). Regarding Xcc, this bacterium exhibited a constant increase in growth in filtrates of cattle and sheep manures. On the other hand, the growth curves of Xcc showed noticeable steps at $18 \mathrm{~h}$ or $26 \mathrm{~h}$ post inoculation, in the case of horse or swine manure filtrates, respectively (Fig. 5).

Table 3. Growth of bacterial phytopathogens in the semi-solid animal manures.

\begin{tabular}{|c|c|c|c|c|c|c|}
\hline \multirow[b]{2}{*}{ Pathogen } & \multirow[b]{2}{*}{ Manure } & \multicolumn{4}{|c|}{ CFUs of tested plant pathogenic bacteria } & \multirow[b]{2}{*}{$120 \mathrm{~h}$} \\
\hline & & $0 \mathrm{~h}$ & $10 \mathrm{~h}$ & $18 \mathrm{~h}$ & $26 \mathrm{~h}$ & \\
\hline \multirow{4}{*}{$\mathrm{Pba}$} & Cattle & $4.3 \pm 3.4$ & $529 \pm 58$ & L & NA & NA \\
\hline & Horse & $4.2 \pm 5.1$ & $560 \pm 40$ & L & NA & NA \\
\hline & Swine & $4.3 \pm 4.3$ & $497 \pm 45$ & L & NA & NA \\
\hline & Sheep & $6.0 \pm 6.8$ & $316 \pm 54$ & $622 \pm 24^{3 L}$ & NA & NA \\
\hline \multirow{4}{*}{ Pсc } & Cattle & $1.8 \pm 1.3$ & $607 \pm 22^{3 L}$ & L & NA & NA \\
\hline & Horse & $2.7 \pm 3.2$ & $580 \pm 57$ & $\mathrm{~L}$ & NA & NA \\
\hline & Swine & $4.5 \pm 4.4$ & $368 \pm 51$ & L & NA & NA \\
\hline & Sheep & $5.8 \pm 7.5$ & $539 \pm 26^{1 L}$ & $L$ & NA & NA \\
\hline \multirow{4}{*}{ Rsol } & Cattle & $0.3 \pm 0.5$ & $270 \pm 57$ & $562 \pm 56$ & L & NA \\
\hline & Horse & $5.7 \pm 7.7$ & $371 \pm 48$ & $L$ & NA & NA \\
\hline & Swine & $5.5 \pm 5.8$ & $332 \pm 67$ & $519 \pm 29$ & $645 \pm 0.0^{5 L}$ & $\mathrm{~L}$ \\
\hline & Sheep & $4.3 \pm 6.4$ & $290 \pm 66$ & $562 \pm 37$ & L & NA \\
\hline \multirow{4}{*}{ Xcc } & Cattle & $1.8 \pm 1.9$ & $88 \pm 43$ & $213 \pm 42$ & $571 \pm 38.4$ & $\mathrm{~L}$ \\
\hline & Horse & $4.2 \pm 6.8$ & $297 \pm 43$ & $529 \pm 23$ & L & NA \\
\hline & Swine & $2.0 \pm 2.1$ & $79 \pm 34$ & $265 \pm 43$ & $427 \pm 55.6$ & $L$ \\
\hline & Sheep & $4.3 \pm 6.4$ & $290 \pm 66$ & $562 \pm 37$ & $\mathrm{~L}$ & NA \\
\hline
\end{tabular}

Depicted values are means \pm S.D. Data originate from 2 biological replicates with 2 technical repetitions. L, bacterial lawn; NA, not analyzed. Superscripts with numbers show how many of the plate repeats exhibited bacterial lawn growth. 


\section{Bacterial growth in sterilized animal manures}

All of the tested phytopathogens (Pcc, Pba, Rsol and Xcc) did not grow in the autoclaved semi-solid poultry manure. Concerning semi-solid fertilizers of cattle, horse, swine and sheep origin, Rsol and Xcc exhibited a slower growth rate in these media than Pcc and Pba (Table 3). The number of $\mathrm{Pba} C F U s$ was reduced in sheep manure in comparison to manures of other origin. Alike to what was observed for the growth of Pcc in the manure filtrates (Fig. 3), this bacterium showed the highest increase in CFUs while cultured in the cattle manure, and the most delayed one in the swine manure (Table 3). On the other hand, Rsol exhibited the most efficient growth in the horse manure, which is consistent with the data collected from manure filtrates (Fig. 4 and Table 3). As it was shown before, the growth rate of Rsol in cattle, swine and sheep semi-solid manures was very similar. In the case of Xcc, this pathogen utilized cattle and swine semi-solid manures less efficiently than the fertilizers of horse or sheep origin (Table 3).

\section{DISCUSSION}

Organic manures have been widely used to supply plants with the essential elements like nitrogen, phosphorus, potassium, sodium, copper, zinc, calcium, selenium, manganese, sulphur, and magnesium (Reynolds, 2000). Application of animal manures increases the fertility of the soil not only for one year, but for multiple growing seasons. Our study was aiming at answering the question whether plant pathogenic bacteria can also benefit from this rich source of available nutrients. So far, the environmental concerns focused on spreading human pathogens together with the dispersal of animal manures on the fields. The main reason for this is that farmyard animals are reservoirs of bacteria capable of causing zoonotic infections. It is worth to mention that several outbreaks of e. g. gastroenteritis could have been traced to the livestock operations (Pell, 1997). The most frequently isolated human pathogens from cattle, poultry or swine manures include: Salmonella spp., Mycobacterium spp., Brucella spp., Leptospira spp., Chlamydia spp., Rickettsia spp., Klebsiella spp., Listeria monocytogenes, Yersinia enterocolitica, Escherichia coli, Bacillus anthracis, and Clostridium perfringens (Mawdsley et al., 1995). To the best of our knowledge, there was no data up to now on the attempt to detect bacterial phytopathogens in manures or slurries of animal origin. Likewise, plant pathogenic bacteria causing diseases of high economic impact were not tested for their abilities to use animal wastes as the sources of nutrients.

No phytopathogens from the Cms, Dsp, Eam, Pba, Pcc, Rsol and Xcc species were detected by specific PCR reactions no matter what was the origin of the studied manure - cattle, sheep, horse, swine or poultry. The reason for that could be the impaired survival of ingested plant pathogenic bacteria within the livestock intestines. E. coli, a model microorganism from the Enterobacteriaceae family, can develop an extreme acidic resistance to low $\mathrm{pH}$ of the cattle gastrointestinal tract only when grown under mildly acidic conditions. It was reported that the elevated survival of this pathogen correlated with the change in feed supplementation with grain instead of hay (Diez-Gonzalez et al., 1998). Cotta et al. evaluated the phylogenetic population structure of swine faeces and manure storage pits microflora by $16 \mathrm{~S}$ rDNA sequencing. They did not detect any closely related species to plant pathogenic bacteria, and only the members of the following groups: Bacteroides, Sporomusa, Clostridium, Staphylococcus, Abiotrophia, Lactobacilli, Enterococcus, Streptococci, and Acholeplasma-anaeroplasma (Cotta et al., 2003). Our findings might suggest that either plant pathogenic bacteria entering the gastrointestinal tract of farmyard animals do not survive in this harsh environment or are not competitive against the fixed constituents of the faecal microflora. As a next step, we decided to examine the growth of plant pathogenic bacteria - Pba, Pcc, Rsol and Xcc - in manure filtrates and semi-solid autoclaved manures collected from cattle, sheep, horse, swine and poultry.

In our study, we evaluated growth dynamics of the investigated plant pathogenic bacteria in filtrates of animal manures. We also measured the absorbance of noninoculated manure filtrates to exclude the impact of organic matter transformations on optical density within such chemically complex material. As reported for the solid phase of cattle manure, during a composting process lasting for 146 days, the loss of organic matter was above $50 \%$, the $\mathrm{C} / \mathrm{N}$ ratio decreased from 27.2 to 8.7 , cation exchange capacity was 3 -fold higher than the basal level, the amount of cellulose and hemicellulose was reduced to one third of the original level, while the total lignin increased from 19.9 to 30.9\% (Chen et al., 1989). So far, the capacity of plant pathogens to utilize natural fertilizers as the sources of nutrients was not stated, only the suppressive effect of composts originating from waste materials such as hardwood or pine bark, municipal sludge, licorice roots, grape marc or cattle manure on soil-borne fungal plant pathogens Pythium aphanidermatum, Pythium ultimum, Rhizoctonia solani, Fusarium oxysporum, Sclerotium rolfsii and Phytophthora cinnamomi was proven (Hadar \& Mandelbaum, 1992). However, the suppressive effect of composts results from the activity of antagonistic microorganisms that naturally recolonize this material in the course of the cooling process. Aiming for the evaluation of growth of bacterial pathogens in animal manures, we subjected the analyzed waste materials to the process of sterilization by filtration or autoclaving, which negated the biological suppression. Only phage particles could pass through the applied filters, but the presence of specific bacteriophages in investigated manure samples is quite unlikely. Bacteriophages are often targeting only certain subpopulation of bacteria belonging to one species and are highly susceptible to the environmental conditions, like UV radiation, temperature, $\mathrm{pH}$, desiccation and applied pesticides such as copper bactericides (Iriarte et al., 2007). However, no bacteriophages could survive autoclaving in the case of cultures conducted in the semi-solid manure fractions. On the other hand, high pressure and temperature, considered as a rough treatment, could possibly lead to the change and disruption of manure matrix and further contribute to the process of chemical organic matter transformations. The research presented here has shown that poultry manure does not support growth of plant pathogenic bacteria both in the manure filtrate and in the semi-solid autoclaved fraction. We suppose this is due to a higher $\mathrm{pH}$ and greater $\mathrm{Ca}$, $\mathrm{Mg}, \mathrm{N}, \mathrm{P}, \mathrm{K}$ contents (Agri Analysis Inc.) than in the bovine and swine manures. In addition, a crucial issue might be the inability of Pba, Pcc, Rsol, and Xcc to decompose uric acid, the major nitrogenous constituent in this organic fertilizer. It was shown previously that Corynebacterium, Nocardia, Streptomyces, Pseudomonas, Achromobacter and Alcaligenes are capable of decomposing urinic acid either to urea or ammonium and constitute the microflora of poultry litter being responsible for its high $\mathrm{pH}$ (Schefferle, 1965). The other animal manures - cattle, horse, swine and sheep - including filtrates, as well 
as the semi-solid fractions, did support the growth of bacterial plant pathogens with the changes in the relative optical densities of filtrate cultures contained in the range of $0.03-0.22$. Pba and Pcc started multiplying quite instantly after inoculation into all of the tested manure filtrates tested manure filtrates. Their growth was the most efficient in the filtrate of cattle manure. Rsol and Xcc showed delayed growth in comparison to the pectinolytic bacteria under all tested conditions, which is also observable in the regular laboratory-use microbiological media. Though the growth dynamics of the analyzed species in different organic fertilizers of animal origin (semi-solid and filtrates) is unequal, all of the investigated bacterial plant pathogens were proven to be able to use cattle, horse, swine and sheep manures as the sources of nutrients.

In conclusion, Cms, Dsp, Pba, Pcc, Rsol, Xcc and Eam were not detected in the collected cattle, horse, swine, chicken or sheep manure samples. All of the tested phytopathogens did not grow in the manure filtrates or the semi-solid manures of the poultry origin. Cattle, horse, swine and sheep manures, both filtrates and the semi-solid ones, were utilized by Pba, Pcc, Rsol, and Xcc as the nutrient sources.

\section{Acknowledgements}

We are very grateful to Professor Ewa Lojkowska for fruitful discussions, valuable advice, everlasting support and proofreading of this manuscript. Moreover, we would like to thank all of the farmers who provided animal manures collected from their livestock for the use of this study.

\section{Financial support}

This study was supported by grant from The National Science Center in Poland via grant number N N310 $732140(7321 / \mathrm{B} / \mathrm{P} 01 / 2011 / 40)$ to Wojciech Sledz.

\section{REFERENCES}

Agarwal PC, Mortensen CN, Mathur SB (1989) Seedborne disease and seed health testing of rice. In Technical Bulletin 3. Phytopathol Pap 30. Danish Government Institute of Seed Pathology for Developing Countries and CAB International Mycological Institute. https:// www.cabdirect.org/cabdirect/abstract/19901143563

Bereswill S, Pahl A, Bellemann P, Zeller W, Geider K (1992) Sensitive and species-specific detection of Erwinia amylovora by polymerase chain reaction analysis. Appl Environ Microbiol 58: 3522-3526. http:// aem.asm.org/content/58/11/3522.short

Bertani G (1951) Studies on lysogenesis I: the mode of phage liberation by lysogenic Escherichia coli. J Bacteriol 62: 293-300. https://www. ncbi.nlm.nih.gov/pmc/articles/PMC386127/

Bonn WG, van der Zwet T (2000) In Distribution and economic importance of fire blight. Fire blight: the disease and its causative agent, Eminia amylovora. pp 37-53. DOI: 10.1079/9780851992945.0037

Burnhill P, Chalmers AG, Fairgrieve J (1994) In The British Survey of Fertiliser Practice 1993: Fertiliser Use on Farm Crops. HSMO, London, UK. https://www.gov.uk/government/uploads/system/uploads/ attachment_data/file/229967/fertiliseruse-2002report.pdf

Chen Y, Inbar Y, Hadar Y, Malcolm RL (1989) Chemical properties and solid-state CPMAS 13C-NMR of composted organic matter. Sci Total Environ 81: 201-208. DOI: 10.1016/0048-9697(89)90126-5

Cotta MA, Whitehead TR, Zeltwanger RL (2003) Isolation, characterization and comparison of bacteria from swine faeces and manure storage pits. Environ Microbiol 5: 737-745. DOI: 10.1046/j.1462-2920.2003.00467.x

Crumrine MH, Foltz VD (1969) Survival of Salmonella montevideo on wheat stored at constant relative humidity. Appl Microbiol 18: 911914. http://aem.asm.org/content/18/5/911.short

Czajkowski R, Perombelon MCM, van Veen JA, van der Wolf JM (2011) Control of blackleg and tuber soft rot of potato caused by Pectobacterium and Dickeya species: a review. Plant Pathol 60: 9991013. DOI: $10.1111 /$ j.1365-3059.2011.02470.x
Denny T (2007) Plant pathogenic Ralstonia species. In Plant-associated bacteria pp 573-644. Springer Netherlands. ISBN 978-1-4020-4538-7

Diez-Gonzalez F, Callaway TR, Kizoulis MG, Russell JB (1998) Grain feeding and the dissemination of acid-resistant Escherichia coli from cattle. Science 281: 1666-1668. DOI: 10.1126/science.281.5383.1666

Elphinstone JG, Allen C, Prior P, Hayward AC (2005) In The current bacterial wilt situation: a global overview. Bacterial wilt disease and the Ralstonia solanacearum species complex. pp 9-28. ISBN 978-0-89054329-0

Frechon D, Exbrayat P, Helias V, Hyman LJ, Jouan B, Llop P, Lopez MM, Payet N, Pérombelon MCM, Toth IK, van Beckhoven JRCM, van der Wolf JM, Bertheau Y (1998) Evaluation of a PCR kit for the detection of Erwinia carotovora subsp. atroseptica on potato tubers. Potato Res 41: 163-173. DOI: 10.1007/BF02358439

French ER, Gutarra L, Aley P, Elphinstone J (1995) Culture media for Pseudomonas solanacearum isolation, identification and maintenance. Fitopatologia 30: 126-130. https://www.google.pl/url? sa=t\&rct=j\&q $=\&$ esrc $=$ s\&source $=$ web\&cd $=1 \&$ ved $=0$ ahUKEwjR1NW14NPSAh VG8ywKHfkRDmUQFggcMAA\&url=https $\% 3 \mathrm{~A} \% 2 \mathrm{~F} \% 2$ Fresearch. cip.cgiar.org $\% 2 \mathrm{Fconfluence} \% 2 \mathrm{Fdownload} \% 2 \mathrm{Fattachments} \% 2 \mathrm{~F} 5106$ $1560 \% 2$ FPublication $\% 2520$ French- $\% 2520$ Culture $\% 2520$ media $\% 252$ 0Rs-1995.doc $\% 3$ Fversion $\% 3 \mathrm{D} 1 \% 26$ modificationDate $\% 3 \mathrm{D} 13486198$ 07000\%26api\%3Dv2\&usg=AFQjCNHNz9DClFkYF6VvucncuQq27 I50RA\&cad=rja

Hadar Y, Mandelbaum R (1992) Suppressive compost for biocontrol of soilborne plant pathogens. Phytoparasitica 20: S113-S116. DOI: 10.1007/BF02980420

Haynes RJ, Naidu R (1998) Influence of lime, fertilizer and manure applications on soil organic matter content and soil physical conditions: a review. Nutr Cycl Agroecosys 51: 123-137. DOI: 10.1023/A:1009738307837

Hooda PS, Edwards AC, Anderson HA, Miller A (2000) A review of water quality concerns in livestock farming areas. Sci Total Environ 250: 143-167. DOI: 10.1016/S0048-9697(00)00373-9

Hugouvieux-Cotte-Pattat N, Condemine G, Nasser W, Reverchon, S (1996). Regulation of pectinolysis in Erwinia chrysanthemi. Annu Rev Microbiol 50: 213-257. DOI: 10.1146/annurev.micro.50.1.213

Iriarte FB, Balogh B, Momol MT, Smith LM, Wilson M, Jones JB (2007) Factors affecting survival of bacteriophage on tomato leaf surfaces. Appl Environ Microb 73: 1704-1711. DOI: 10.1128/ AEM.02118-06

Jones PW (1980) Health hazards associated with the handling of animal wastes. Vet Rec 106: 4-7. DOI: 10.1136/vr.106.1.4

Jones PW, Hall GA (1975) Detection of Salmonella infection in pig herds by examination of slurry. Vet Rec 97: 351-352. DOI: 10.1136/ vr.97.18.351

Jongbloed AW, Lenis NP (1998) Environmental concerns about animal manure. J Animal Sci 76: 2641-2648. DOI: 10.2527/1998.76102641x

Kang HW, Kwon SW, Go SJ (2003) PCR-based specific and sensitive detection of Pectobacterium carotovorum ssp. carotovorum by primers generated from a URP-PCR fingerprinting-derived polymorphic band. Plant Pathol 52: 127-133. DOI: 10.1046/j.13653059.2003.00822.x

Kearney TE, Larkin MJ, Frost JP, Levett PN (1993) Survival of pathogenic bacteria during mesophilic anaerobic digestion of animal waste. J Appl Bacteriol 75: 215-219. DOI: 10.1111/j.1365-2672.1993. tb02768.x

Killham K (1994) In Soil ecology. Cambridge University Press. ISBN: 9780521435215

Leben C (1974) Survival of plant pathogenic bacteria. In Obio Agricultural Research and Development Center. Special circular. 100. http:// hdl.handle.net/1811/71830. http:// hdl.handle.net/1811/71830

Management Field Handbook. Washington, D.C

Mansfield J, Genin S, Magori S, Citovsky V, Sriariyanum M, Ronald P, Dow M, Verdier V, Beer SV, Machado MA, Toth IAN (2012) Top 10 plant pathogenic bacteria in molecular plant pathology. Mol Plant Pathol 13: 614-629. DOI: 10.1111/j.1364-3703.2012.00804.x

Mawdsley JL, Bardgett RD, Merry RJ, Pain BF., Theodorou MK (1995). Pathogens in livestock waste, their potential for movement through soil and environmental pollution. Appl Soil Ecol 2: 1-15. DOI: 10.1016/0929-1393(94)00039-A

Mikkelsen L, Elphinstone J, Jensen DF (2006) Literature review on detection and eradication of plant pathogens in sludge, soils and treated biowaste. In Desk study on bulk density. Bruxelles: The European Commission DG RTD under the Framework, 6. ftp://130.112.2.101/ pub/www/society/horizontal/Hor_desk_30_plant_pathogens.pdf

Morse EV, Duncan MA (1974) Salmonellosis - an environmental health problem. J A Vet Med Assoc 165: 1015-1019

Nassar A, Darrasse A, Lemattre M, Kotoujansky A, Dervin C, Vedel R, Bertheau Y (1996) Characterization of Erwinia chrysanthemi by pectinolytic isozyme polymorphism and restriction fragment length polymorphism analysis of PCR-amplified fragments of pel genes. Appl Environ Microbiol 62: 2228-2235. http://aem.asm.org/ content $/ 62 / 7 / 2228$.short 
Olsen JE, Larsen HE (1987) Bacterial decimation times in anaerobic digestions of animal slurries. Biol waste 21: 153-168. DOI: 10.1016/0269-7483(87)90121-2

Park YJ, Lee BM, Hahn JH, Lee GB, Park DS (2004) Sensitive and specific detection of Xanthomonas campestris pv. campestris by PCR using species-specific primers based on $b r p F$ gene sequences. Microbiol Res 159: 419-423. DOI: 10.1016/j.micres.2004.09.002

Pastrik KH (2000). Detection of Clavibacter michiganensis ssp. sepedonicus in potato tubers by multiplex PCR with coamplification of host DNA. E J Plant Pathol 106: 155-165. DOI: 10.1023/A:1008736017029

Pell AN (1997). Manure and microbes: public and animal health problem? J Dairy Sci. 80: 2673-2681. DOI: 10.3168/jds.S00220302(97)76227-1

Perombelon MCM (2002) Potato diseases caused by soft rot erwinias: an overview of pathogenesis. Plant Pathol 51: 1-12. DOI: 10.1046/ j.0032-0862.2001. Shorttitle.doc.x

Qian W, Jia Y, Ren SX, He YQ, Feng JX, Lu LF, Sun Q, Ying G, Tang DJ, Tang H, Wu W, Hao P, Wang L, Jiang BL, Zeng S, Gu WY, Lu G, Rong L, Tian Y, Yao Z, Fu G, Chen B, Fang R, Qiang B, Chen Z, Zhao GP, Tang JL, He C (2005) Comparative and functional genomic analyses of the pathogenicity of phytopathogen Xanthomonas campestris pv. campestris. Genome Res 15: 757-767. DOI: $10.1101 / \mathrm{gr} .3378705$

Reynolds DA (2000) Effects of liquid swine manure and its components on Heterodera glycines population densities and soybeangrowth and yield. Retrospective Theses and Dissertations. Paper 12357. http://lib.dr.iastate.edu/rtd/12357

Roberts RG, Hale CN, Van der Zwet T, Miller CE, Redlin SC (1998) The potential for spread of Erminia amylovora and fire blight via commercial apple fruit; a critical review and risk assessment. Crop Prot 17: 19-28. DOI: 10.1016/S0261-2194(98)80008-2

Sauerbeck DR (1982) Influence of crop rotation, manurial treatment and soil tillage on the organic matter content of German soils. In Soil Degradation, Proceedings of the EEC Seminar held in Wageningen. Netherlands, Boels D, Davies DB, Johnston AE eds, pp 163-179. Rotterdam, A A Balkema

Schefferle HE (1965) The decomposition of uric acid in built up poultry litter. J Appl Bacteriol 28: 412-420. DOI: 10.1011/j.13652672.1965.tb02171.x
Seal SE, Jackson LA, Young JP, Daniels MJ (1993) Differentiation of Pseudomonas solanacearum, Pseudomonas syzgii and the blood disease bacterium by partial $16 \mathrm{~S}$ rRNA sequencing: construction of oligonucleotide primers for sensitive detection by polymerase chain reaction. J Gen Microbiol 139: 1587-1594. DOI: 10.1099/00221287139-7-1587

Smith KA, Chalmers AG, Chambers BJ, Christie P (1998) Organic manure phosphorus accumulation, mobility and management. Soil Use Manage 14: 154-159. DOI: 10.1111/j.1475-2743.1998.tb00634.x

Tappouni YA (1984) The fate of Salmonella in anaerobic digestion. PhD Thesis. University College, Cardiff, UK

Toth IK, Van Der Wolf JM, Saddler G, Lojkowska E, Hélias V, Pirhonen M, Elphinstone JG (2011) Dickeya species: an emerging problem for potato production in Europe. Plant Pathol 60: 385-399. DOI: $10.1111 /$ j.1365-3059.2011.02427.x

Tsror L, Erlich O, Lebiush S, Hazanovsky M, Zig U, Slawiak M, Grabe G, Van Der Wolf JM, Van de Haar JJ (2009) Assessment of recent outbreaks of Dickeya sp. (syn. Envinia chrysanthemi) slow wilt in potato crops in Israel. E J Plant Pathol 123: 311-320. DOI: 10.1007/s10658-008-9368-0

Tucker JF (1967) Survival of salmonellae in built-up litter for housing of rearing and laying fowls. Brit Vet J 123: 92

USDA-NRCS (1992) In National Engineering Handbook, Part 651, Agricultural Waste

van der Zwet T, Beer SV (1995) Fire blight - Its nature, prevention, and control. 2nd edn. United States Department of Agriculture Bulletin 631. ISBN 0160500613, 9780160500619

Williams IE, Benson ST (1978) Survival of Salmonella typhimurium in poultry feed and litter at three temperatures. Avian Dis 22: 742-747. DOI: $10.2307 / 1589652$

Zhao L, Dong YH, Wang H (2010) Residues of veterinary antibiotics in manures from feedlot livestock in eight provinces of China. Sci Total Environ 408: 1069-1075. DOI: 10.1016/j.scitotenv.2009.11.01

Zwet T, Keil HL (1979) Fire blight, a bacterial disease of Rosaceous plants. Agriculture Handbook, Science and Education Administration 510. ISSN 0065-4612 